\title{
Transient cataracts in a diabetic child with hyperosmolar coma
}

\author{
G. A. BROWN AND D. BURMAN \\ From the Departments of Ophthalmology and Paediatrics, United Bristol Hospitals
}

Temporary lens opacities in diabetic coma were noted by Lawrence, Oakley, and Barne (1942) and thought to be common if the lens was carefully examined. This does not appear to have been frequently discussed, but Sheldon and Pyke (1968) showed pictures of opacities in the lens of a girl aged ro years, which cleared rapidly with treatment of the diabetic coma. Neuberg, Griscom, and Burns (1958) found only six documented case reports to show acute development and complete reversal of diabetic cataracts and four cases in which the development was unknown but clearing occurred completely.

Because only Lawrence and others (1942) noticed complete opacification of the lens in diabetic coma, we thought it valuable to report this case of transient complete opacification of both lenses, complicating hyperosmolar, hyperglycaemic, hypernatraemic coma in a diabetic child of nearly 4 years old; this type of diabetic coma is rare in childhood (McCurdy, 1970).

\section{Case report}

This normal baby girl was first admitted soon after her second birthday with diabetic precoma. After rehydration, she was stabilized on a diet containing $\mathrm{I}$ I $\mathrm{g}$. carbohydrate and 8 units of soluble insulin in the morning and 4 units at night.

One month before her $4^{\text {th }}$ birthday she was re-admitted with a history of "strange behaviour", anorexia, polyuria, polydipsia, and misery, but without diarrhoea or vomiting, which had been present for I week.

\section{Examination}

She was very confused, agitated, unco-operative, and unresponsive, but moving all four limbs. The eyes were sunken and the tongue dry and furred, but the elasticity of the skin was not abnormal. The plantar reflexes were extensor but no localizing neurological signs were noted. The fundi and lenses were normal. Blood pressure $100 / 75 \mathrm{~mm}$. $\mathrm{Hg}$; pulse rate $160 / \mathrm{min}$. with a poor pulse volume; respiration $40 / \mathrm{min}$., but not typically acidotic.

\section{Laboratory examination}

Plasma urea $136 \mathrm{mg}$./10o ml.; plasma sodium $168 \mathrm{mEq} / \mathrm{l}$; plasma potassium $4.0 \mathrm{mEq} / \mathrm{l}$.; plasma chloride $133 \mathrm{mEq} / \mathrm{l}$; plasma bicarbonate $16 \mathrm{mEq} / \mathrm{l}$; true blood glucose $2,000 \mathrm{mg}$./100 ml.; plasma ketones present but not measured.

Urine contained 2 per cent. glucose and ketones ++ .

Lumbar puncture normal apart from $300 \mathrm{mg}$./ $100 \mathrm{ml}$. sugar.

Her weight was $15.1 \mathrm{~kg}$., which was $\mathrm{I} \cdot \mathrm{I} \mathrm{kg}$. more than the weight recorded in the out-patients department 2 weeks earlier. 


\section{Diagnosis}

Diabetic hyperosmolar dehydration.

\section{Treatment}

In the first 6 hours 60 units of soluble insulin were given, half intravenously, with $360 \mathrm{ml}$. normal saline and $\mathrm{I} 50 \mathrm{ml}$. half normal saline with 2.29 per cent. Dextrose containing $25 \mathrm{mEq}$ potassium/litre. Ampicillin $250 \mathrm{mg}$. 6-hrly and phenobarbitone $30 \mathrm{mg}$. 8-hrly were also given. The child became very stiff with opisthotonos 3 hours after admission but improved with $10 \mathrm{mg}$. intravenous diazepam and this was repeated approximately every $8 \mathrm{hrs}$.

\section{Progress}

$7 \mathrm{hrs}$ after admission the true blood glucose was $80 \mathrm{mg}$./ $100 \mathrm{ml}$.; blood urea $54 \mathrm{ml}$./ $100 \mathrm{ml}$.; bicarbonate $23 \mathrm{~m} \mathrm{Eq} / \mathrm{l}$.; other electrolytes remained the same. By this time only $90 \mathrm{ml}$. urine had been passed and none in the past $4 \mathrm{hrs}$. In view of the anuria and development of opisthotonos $70 \mathrm{ml}$. 20 per cent. mannitol was given intravenously. This produced a diuresis and the rate of intravenous drip continued at $25 \mathrm{ml} . / \mathrm{hr}$, which is approximately the daily requirement for a child of this age. When the low blood sugar was recorded, $10 \mathrm{ml} .50$ per cent. dextrose was given every $2 \mathrm{hrs}$, but the Dextrostix always showed a blood sugar approximately $100 \mathrm{mg}$./ $100 \mathrm{ml}$.

$20 \mathrm{hrs}$ after admission both lenses were completely opaque and no red reflex could be seen at all. The electrolyte picture at this time was blood urea $42 \mathrm{mg}$. $/$ roo ml.; plasma sodium $165 \mathrm{mEq} / \mathrm{l}$; potassium $3.0 \mathrm{~m} \mathrm{Eq} / 1$.; chloride $123 \mathrm{mEq} / \mathrm{l}$; bicarbonate $27 \mathrm{mEq} / \mathrm{l}$.; true blood glucose $155 \mathrm{mg}$./ 100 ml. Intravenous fluid was continued at the same rate and $4 \mathrm{hrs}$ later a red rim could be seen around the lens opacity.

$29 \mathrm{hrs}$ after admission the lens had a dense stellate central area, which $3 \mathrm{hrs}$ later had fragmented and was noticed to be involving both the anterior and posterior cortex (Figure). $24 \mathrm{hrs}$ after this was first noticed, there were just a few opacities scattered in the lenses and some of these were in the form of bubbles. $12 \mathrm{hrs}$ later $(36 \mathrm{hrs}$ after the onset of the opacities) the lenses were completely normal. Throughout this period of $36 \mathrm{hrs}$ the electrolytes, urea, and sugar did not change significantly from the figures last noted.

4 days after admission the electrolytes had returned completely to normal and the blood glucose remained between 100 and $300 \mathrm{mg}$./ $100 \mathrm{ml}$. At this time the child regained consciousness and started talking. She has since made a complete recovery neurologically and now attends a normal school. I6 months later the lenses were absolutely clear on slit-lamp examination.

\section{Comment}

There is no doubt that on admission this patient showed the characteristics of a severe case of hyperosmolar, nonketotic diabetic coma, as described in children by Rubin, Kramer, and Drash (1969). The calculated serum osmolality

$$
\left[2 \text { (serum Na mEq/l) }+\frac{\text { blood sugar in } \mathrm{mg} \text {. } / \mathrm{loo} \mathrm{ml} .}{\mathrm{I} 8}\right]
$$

was $447 \mathrm{mOsm} / \mathrm{l}$., compared with the normal in childhood of $297 \pm 2$ (Rubin and others, 1969). Although ketones were present in the urine and blood, they were not sufficient to increase the unidentified ion gap beyond the normal of $23 \mathrm{mEq} / \mathrm{l}$. Unlike most of the cases described by Rubin and others ( 1969 ), this child was neurologically normal, had previously been diagnosed as diabetic, and recovered with no residual disability.

Treatment of this condition is difficult in adults (McCurdy, 1970) and in children (Rubin and others, 1969), and, with our lack of experience, we relied upon the principles we use to treat hypernatraemic dehydration in infants-i.e. restoration of vascular volume with normal saline or plasma and slow replacement of intracellular electrolytes and water 

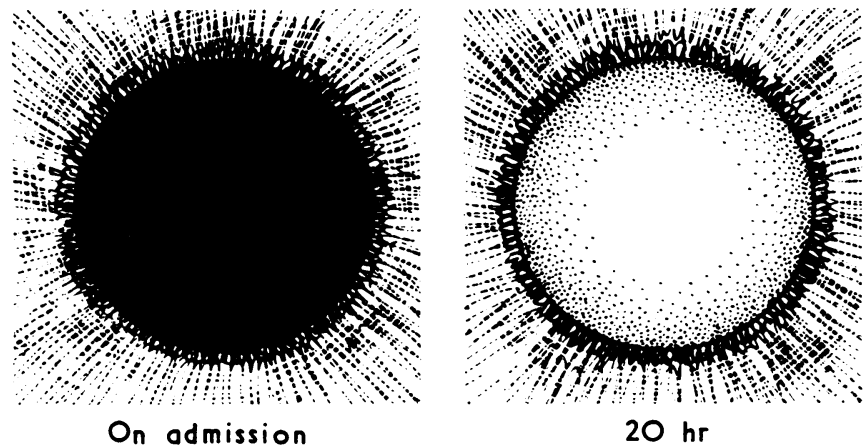

$20 \mathrm{hr}$

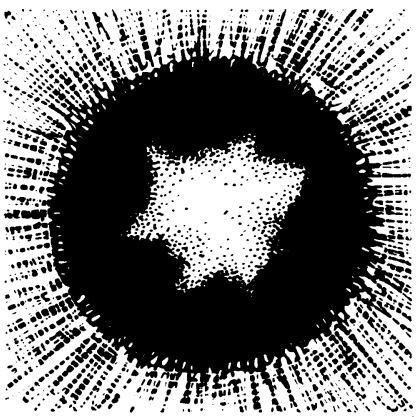

$28 \mathrm{hr}$

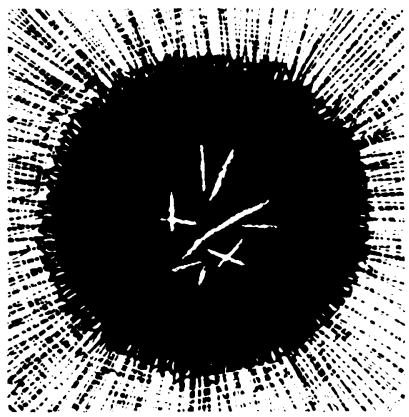

$31 \mathrm{hr}$

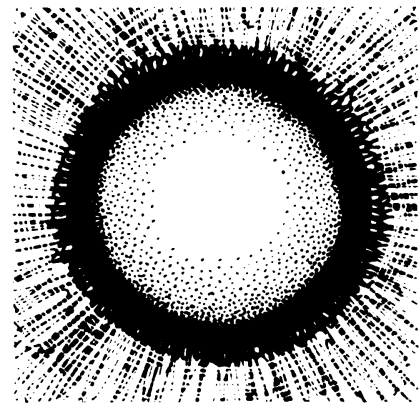

$24 \mathrm{hr}$

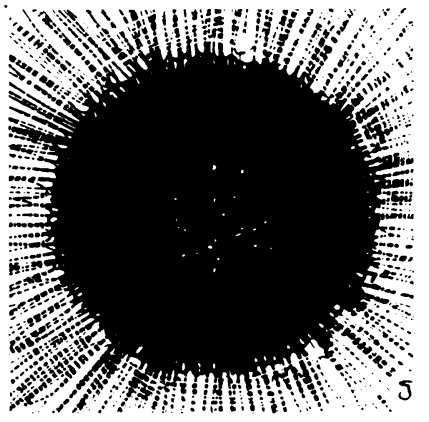

$44 \mathrm{hr}$

FIGURE Aptearances of lens related to time after admission

by giving the daily requirements of fluid containing at least $50 \mathrm{mEq} / \mathrm{l}$. of sodium. The use of lower concentrations of saline causes a rapid reduction of serum osmolality and cerebral oedema, possibly leading to permanent neurological damage (Finberg, 1969). This child developed opisthotonos and generalized stiffness and these were probably signs of cerebral oedema due to reduction of serum osmolality, caused by the rapid drop in the true blood glucose. This cerebral oedema was treated successfully by diazepam and mannitol.

In the non-diabetic child a relationship between hypernatraemia and hyperglycaemia is now clearly established (Stevenson and Bowyer, 1970). Jung and Done (1969) believed that many cases of "transient diabetes" in the newborn were in fact not diabetic at all, but that the biochemical picture was due to insufficient dilution of the infant feeds. Burman and Glaspole (1964) attributed the combination of hyperglycaemia and hypernatraemia to an excessive carbohydrate intake as treatment for gastroenteritis. Stevenson and Bowyer (1970) suggested that, when this combination occurred in gastroenteritis, the release of glucose was secondary to the hypernatraemia and there is experimental evidence to support this (Sotos, Dodge, and Talbot, I962; Nitzan and Zelmanovsky, 1968). The association between hyperglycaemia and hypernatraemia has also been noted heatstroke and this is then attributed to a stress reaction (Monteleone and Keefe, r 969). Whatever the mechanism, the association of hyperglycaemia in non-diabetic infants certainly occurs and in a case reported by Jung and Done (1969) the blood sugar was as high as $970 \mathrm{mg}$. $/ \mathrm{I} 00 \mathrm{ml}$. There may then be a vicious circle in hyperosmolar nonketotic diabetic coma, whereby the hypernatraemia further exaggerates the hyperglycaemia. This may account for the extremely high blood sugars which have been observed and for the danger of giving too much insulin (McCurdy, I970). 
By the time complete opacification of the lenses was noticed in our patient, the blood urea had fallen from 136 to $42 \mathrm{mg}$. $/ \mathrm{r} 00 \mathrm{ml}$., and the bicarbonate had risen from 16 to $29 \mathrm{mEq} / \mathrm{l}$. The true blood glucose had fallen from 2,00o to $155 \mathrm{mg} / \mathrm{I}$ oo $\mathrm{ml}$. and the calculated serum osmolality from 447 to $339 \mathrm{mOsm} / \mathrm{l}$. The major changes obviously $\overrightarrow{\vec{A}}$ took place in the sugar and the serum osmolality and these changes may well be relatedo to the development of the cataracts. Experimentally, if the lens is exposed to a high concentration of sugar in the aqueous, the intracellular concentration of polyols increases significantly (van Heyningen, 1959) and this accumulation is significantly greater in $\varrho$ younger than older animals (Kinoshita, Merola, and Tung, 1968). When the sugar is glucose, sorbitol and fructose, normally present in the lens, increase greatly. When the $\vec{\circ}$ sugar is galactose, as in most experimental work, then dulcitol is found in the lens. Thus both osmolality of the lens and aqueous are increased. In our patient, treatment producedo a sudden, large decrease in the osmolality of the serum, and so of the aqueous, leading too. hydration of the lens. If, as is likely, the lens still retains an increased sugar content,, the osmotic swelling of the lens is increased further. This in turn damages the sodium and potassium pumps in the lens (Kinoshita, Merola, and Hayman, I965). Theset pumps normally maintain a high potassium and a low sodium level inside the lens ands are essential to maintain a high concentration of negatively charged macromolecules (Duncan and Groghan, I969). The electropotential differences across individual lens fibres and across the lens capsule have an active ion-pumping effect which is reduced in ${ }^{\mathbb{D}}$ a hydrated lens (Sperelakis and Potts, 1959). Sodium therefore accumulates, and with ite more water, and the potassium concentration decreases. The aminoacid pump also becomes defective and protein metabolism can be interfered with through decreasedo diffusion of amino acids from the aqueous into the lens (Dische, r968). If the cataract is transient, as in our patient, it is unlikely that actual coagulation of the lens protein hasa occurred. An alternative and more likely explanation is suggested by Philipson (1969) in the hydropic lens of experimental galactose cataracts, he found vacuoles and irregular interfaces between differing protein concentrations in the lens, and measurement of the angular distribution of scattered light supports his theory that light scattering is the cause of the apparent opacification of the lens.

It is thus possible to see that, in our patient, the reduction in serum and aqueous osmolality after a period of hyperglycaemia could readily lead to lens hydration and an influx of sodium, exaggerated by the hypernatraemia. The hydration of the lens, if prolonged would cause loss of transparency through interference with the protein metabolism of the lens fibres. In the transient cataracts in our patient, it is possible that light scattering byf the swollen lens fibres may be a more likely explanation.

Many of the acute cataracts in diabetes, discussed by Lawrence and others (1942) and by Neuberg and others (1958), occurred after treatment was begun, and may be relatedo to changes in hydration and blood sugar. Only three cases (Lawrence and others, 1942 ; Alt, I906; Neuberg and others, 1958) took only hours to develop, and only two (Lawrencew and others, 1942; Sheldon and Pyke, 1968) returned to normal in a matter of hours? Neither of these two patients had the complete opacification of the lenses that we observed? and in neither are the biochemical details given. Our patient's cataracts appeared tof be the result of a very unusual combination of factors.

\section{Summary}

A child was admitted to hospital with hyperosmolar diabetic coma. 20 hours aftero 
admission both lenses were completely opaque but 36 hours later they were completely normal again. The mechanism of this phenomenon is discussed.

We are grateful to Mr. Gary James, Department of Medical Illustration, for the drawing.

\section{References}

ALT, A. (1906) Amer. F. Ophthal., 23, 294

BURMAN, D., and GLASPOLE, D. W. (1964) Lancet, 2, 208

DISCHE, z. (1968) In "Biochemistry of the Eye", XX International Congress of Ophthalmology,

August, 1966, ed. M. U. Dardenne and J. Nordmann, p. 413. Karger, Basel

DUNCAN, G., and Croghan, P. c. (1969) Exp. Eye Res., 8, 421

FinBerg, L. (1969) Advanc. Pediat., 16, 325

HEYNINGEN, R. VAN (1959) Nature (Lond.), 184, 194

Jung, A. L., and done, A. K. (1969) Amer. F. Dis. Child., 118, 859

kinoshita, J. H., merola, L. O., and hayman, s. (1965) J. biol. Chem., 240, 3 Io

- — , and TUNG, B. (1968). In "Biochemistry of the Eye", XX International Congress

of Ophthalmology, August, I966, ed. M. U. Dardenne and J. Nordmann, p. 373. Karger, Basel LAWRENCE, R. D., OAKLEY, W., and BARNE, I. G. (1942) Lancet, 2, 63

McGURDY, D. K. (1970) Med. Clin. N. Amer., 54, 683

monteleone, J. A., and Keefe, D. M. (1969) Pediatrics, 44,737

NEUBERG, H. W., Griscom, J. H., and BURNS, R. P. (1958) Diabetes, 7, 21

NITZAN, M., and ZELMANOVSKY, s. (1968) Ibid., 17, 579

PHILIPSON, B. (1969) Acta ophthal. (Kbh.), 103, Suppl. 25

RUBin, H. M., KRAMER, R., and DRASh, A. (1969) F. Pediat., 74, 177

ShEldoN, J., and PYKE, D. A. (1968) In "Clinical Diabetes and Its Biochemical Basis", ed.

W. G. Oakley, D. A. Pyke, and K. W. Taylor, p. 420. Blackwell Scientific Publications, Oxford sotos, J. F., DODGe, P. R., and talbot, N. B. (1962) Pediatrics, 30, 180

SPERELAKis, N., and POTTS, A. (1959) Amer. F. Ophthal., 47, no. 1, pt 2, p. 395

Stevenson, R. E., and BoWyer, F. B. (1970) F. Pediat., 77, 818 